NBER WORKING PAPER SERIES

IMMIGRATION: AMERICA'S NINETEENTH CENTURY "LAW AND ORDER
PROBLEM"?

Howard Bodenhorn

Carolyn M. Moehling

Anne Morrison Piehl

Working Paper 16266

http://www.nber.org/papers/w16266

NATIONAL BUREAU OF ECONOMIC RESEARCH

1050 Massachusetts Avenue

Cambridge, MA 02138

August 2010

We thank Veronica Hart and Jennifer Chang for exceptional research assistance in entering and cleaning the Pennsylvania prison data. Bodenhorn thanks the Irish American Cultural Institute, Lafayette College and the National Science Foundation (SES-0109165) for financial support. The views expressed herein are those of the authors and do not necessarily reflect the views of the National Bureau of Economic Research.

NBER working papers are circulated for discussion and comment purposes. They have not been peerreviewed or been subject to the review by the NBER Board of Directors that accompanies official NBER publications.

(C) 2010 by Howard Bodenhorn, Carolyn M. Moehling, and Anne Morrison Piehl. All rights reserved. Short sections of text, not to exceed two paragraphs, may be quoted without explicit permission provided that full credit, including $(\mathcal{C}$ notice, is given to the source. 
Immigration: America's nineteenth century "law and order problem"? Howard Bodenhorn, Carolyn M. Moehling, and Anne Morrison Piehl NBER Working Paper No. 16266

August 2010

JEL No. J01,K4,N3

\begin{abstract}
Past studies of the empirical relationship between immigration and crime during the first major wave of immigration have focused on violent crime in cities and have relied on data with serious limitations regarding nativity information. We analyze administrative data from Pennsylvania prisons, with high quality information on nativity and demographic characteristics. The latter allow us to construct incarceration rates for detailed population groups using U.S. Census data. The raw gap in incarceration rates for the foreign and native born is large, in accord with the extremely high concern at the time about immigrant criminality. But adjusting for age and gender greatly narrows that observed gap. Particularly striking are the urban/rural differences. Immigrants were concentrated in large cities where reported crime rates were higher. However, within rural counties, the foreign born had much higher incarceration rates than the native born. The interaction of nativity with urban residence explains much of the observed aggregate differentials in incarceration rates. Finally, we find that the foreign born, especially the Irish, consistently have higher incarceration rates for violent crimes, but from 1850 to 1860 the natives largely closed the gap with the foreign born for property offenses.
\end{abstract}

Howard Bodenhorn

John E. Walker Department of Economics

College of Business and Behavioral Science

201-B Sirrine Hall

Clemson University

Clemson, SC 29634

and NBER

bodenhorn@gmail.com

Carolyn M. Moehling

Department of Economics

Rutgers University

75 Hamilton Street

New Brunswick, NJ 08901-1248

and NBER

cmoehling@econ.rutgers.edu
Anne Morrison Piehl

Department of Economics

Rutgers, The State University of New Jersey

New Jersey Hall

75 Hamilton Street

New Brunswick, NJ 08901-1248

and NBER

apiehl@economics.rutgers.edu 


\section{Immigration: America's nineteenth century "law and order problem"?}

Between 1847 and 1858, over three million immigrants arrived in the United States. The arrival rate, which had averaged less than 4 per 1000 of the population in the 1830 s, jumped into the double digits, reaching a peak of nearly 16 in 1851 . This dramatic inflow coincided with a number of social and economic changes. One such change was an increase in crime, particularly violent crime. Violent crime in the U.S. "surged" in the middle of the $19^{\text {th }}$ century just as the foreign-born population reached its peak. Previous research has argued that these two phenomena were strongly linked. Eric Monkkonen (1989) found that immigrants accounted for between one-third and two-thirds of the homicides in New York City between 1852 and 1869 (p. 91). Roger Lane (1979) likewise found that the Irish were disproportionately represented in homicide indictments in Philadelphia between 1839 and 1901 (p. 103).

The research literature, however, leaves many unanswered questions about how the first major wave of immigration affected crime patterns. First, the studies to date have only examined violent crime. Violent crime accounts for a relatively small fraction of total crime and can exhibit different trends, age patterns, and geographic variation than non-violent crime. Moreover, the studies of violent crime suffer from limited or inferential information on nativity. Most historic data sources on crime do not systematically report data on place of birth. Monkkonen, who used a sample of homicide reports from newspapers, reported estimates of immigrant involvement in murder after dropping records where nativity was not reported. This likely biases his findings on the immigrant murder rate upwards. Also without information on nativity, Lane used surnames to infer ethnicity in the Philadelphia court records.

Our study provides a fresh look at the question of immigration and crime in the midnineteenth century using data sets created from the records of Pennsylvania's state prisons from the 1830 s to the 1860 s. These records provide information on the birthplace, age, prior 
occupation, county of conviction, crime, and sentence of all individuals entering the prisons.

The administrative prison data contain a census of all inmates during the covered time period and the quality of the administrative data is very good. These advantages over the data used in previous studies provide more confidence in interpreting the empirical relationships between nativity and crime and also allow us to test a richer set of hypotheses about the level and type of involvement of immigrants in crime and incarceration.

\section{The First Major Wave of Immigration}

In the late-1840s, the U.S. experienced its first wave of mass immigration. The annual number of arrivals increased by a factor of four and remained high for almost a decade (Figure 1). At its peak, the arrival rate represented an addition of nearly 2 percent of the population each year. Most of these new arrivals were fleeing the economic and social upheavals in Europe of the period. Irish immigrants were seeking refuge from the devastation brought about by the potato famine, and German immigrants were escaping the violence and disorder of the social revolution, which was preceded by - and, perhaps, caused by - poor food harvests between 1845 and 1847 and an industrial slump in 1848 (Berger and Spoerer 2001). Thus, a large proportion of mid-nineteenth century immigrants would now be considered economic refugees, though some were driven to migration by political factors. ${ }^{3}$

Nearly from the beginning of the first big wave of immigrants, contemporary observers sounded warnings about the economic and social consequences of the influx of new arrivals. Many contemporaries worried about how well Irish Catholics would assimilate in Protestant

\footnotetext{
${ }^{3}$ Facilitating these mass population movements was a significant decline in transport costs over time. In the early 1840 s, the Cunard Line began operating trans-Atlantic steamers, greatly reducing the cost and time of the voyage to America. In 1825, trans-Atlantic passage had cost £20 per head whereas by 1863 , steamer passage was only $£ 4$. $15 \mathrm{~s}$. and passage on a sailing ship was only £2. 17s. 6d. (Thomas 1954, 96).
} 
America, and as early as 1847, an article in the Christian Watchman claimed that "The fact cannot be concealed that [the U.S.] is receiving into its bosom, a vast amount of poverty, ignorance, disease, and crime" (July 2, 1847, page 106). McCaffrey’s (1976) assessment accords with the Watchman's. He contended that the new Irish immigrants of the 1840s and 1850s were the first immigrant group crowded into urban ghettoes and among the first to experience the negative social consequences of living in crowded tenements. Hunger and poverty pushed Irish girls into prostitution and turned Irish boys into muggers and thieves. McCaffrey (1976, p. 68) claimed that the "Irish were America's law and order problem" after 1850. Roughly two decades after the peak of Irish immigration, Eliott (1869) reported a remarkable finding: the number of Irish prisoners in Great Britain's jails had declined from nearly 15,000 in 1851 to fewer than 2,700 in 1865. What disturbed contemporary Americans was Eliott's claim that the smaller number of Irish in Great Britain's jails and prisons was matched by a corresponding increase in the presence of Irish in American jails and prisons. Between the mid-1850s and the mid-1860s Irish immigrants made up about half of all arrestees in Boston and Philadelphia (Handlin 1959, p. 257; Naylor 1979, p. 53). In 1858 the New York Times reported that of the 12,000 arrests made by the New York Police Department over a three month period, 8,000 were Irish and over 2,000 were immigrants from other countries. ${ }^{4}$ The national data available at the time also supported the perception that immigrants were the law and order problem of the day. The 1850 abstract produced by the Census Bureau reported that of the 27,000 persons convicted of crimes in the year ending June 1, 1850, 14,000 were foreign-born (U.S. Bureau of the Census 1853, 29). In an article reporting these data, the New York Times noted, "While we have, therefore, but

\footnotetext{
${ }^{4}$ The statistic that five-sixths of all arrestees were immigrants and two-thirds of all arrestees were Irish immigrants does not seem credible at first, but nearly identical proportions are reported by Handlin (1959, p. 257) for Boston in 1864. Nearly 10,000 of the 13,000 Boston arrestees were Irish immigrants; nearly 1,000 were immigrants from elsewhere. Only about 2,100 arrestees were native-born Americans.
} 
about one foreign resident to nine native whites, there is a fraction over one foreign born criminal to every native, including black and white" (September 24, 1853, p. 4; emphasis in original).

Calls were made to restrict the inflow of new migrants and limit the rights of immigrants already in the U.S. Nativist societies sprung up around the nation and by 1854 , this sentiment had become the cornerstone of a new national political party, the Know-Nothing, or American, party. The Know-Nothing party did not advocate stopping the inflow of new migrants but rather sought to limit the influence of the foreign born on American politics and to exclude two groups of immigrants: paupers and criminals (Jones 1974, 157). The Know-Nothings did not have to try hard to establish a link between crime and immigration. As the author of the New York Times article on the 1858 arrest records for New York City noted, "Police records of this City are, after all, the strongest argument that any Know-Nothing can advance" in support of immigration restrictions (February 22, 1858, p. 4).

The political influence of the Know-Nothing Party declined after its presidential candidate, Millard Fillmore, was roundly defeated in the 1856 elections (Jones 1974, 157). But calls for restrictions on immigration resurfaced with each new wave of immigrants and the perceived connection between immigration and crime remained an integral part of the American discussion. When the first comprehensive immigration law was enacted in 1891, the "inadmissible classes" included persons convicted of crimes or misdemeanors, and the Immigration Act of 1917 included a provision to deport any immigrant who had been in the U.S. five or fewer years and had been sentenced to at least one year in prison, and any immigrant no matter the time spent in the U.S. who had been convicted of a more serious offense or prostitution (Moehling and Piehl 2009). 
Although some accused European countries of intentionally exporting their criminals to the U.S., most of the discussion attributed the criminal behavior of immigrants to disadvantage, disappointment, and the difficulties of adjusting to life in America. ${ }^{5}$ These arguments foreshowed academic theories about immigration and criminality that were developed largely during the third wave of immigration, in the early $20^{\text {th }}$ century. Many early criminologists attributed immigrant crime to the other demographic and social characteristics of immigrants, in particular their high rate of poverty (Taft 1933). Others essentially extended theories of urban life, as immigrants were highly concentrated in the nation's cities (see Bursik 2006 for a review). But some scholars argued that it was the special circumstances faced by immigrants that led them to have different criminal patterns than natives. Thorsten Sellin (1938) emphasized the "culture conflict" faced by immigrants as they try to adjust to a new society and a new set of behavioral norms. Handlin (1959) attributed the social disorder created by Irish immigrants in particular, to the combination of cultural conflict and economic disadvantage: "in no group was there an inherent predilection for crime, but among the Irish the combination of poverty and intemperance created a maladjustment expressed by petty infractions of the rules of society strange to them" (pp. 121-22).

The New York City police records and the 1850 Census data make a strong prima facie case that immigrants had much higher crime rates than natives. However, these data are not as clear-cut evidence of immigrants' disproportionate involvement in crime as they may first appear. Arrests, then as now, are noisy measures of criminal behavior. Arrests are dominated by minor offenses like disorderly conduct, and even for more serious offenses, can be based on

\footnotetext{
${ }^{5}$ In blaming countries for sending their criminals, there are historical parallels with modern debates. Martinez et al. (2003), for example, provide evidence refuting the contention that the Mariel boat lift was an attempt on Cuba's part to empty its prisons of hardened felons. Criminals were among the Marielitos, but most were political prisoners rather than violent felons.
} 
police suspicions rather than the higher evidentiary standards that courts use. In many situations, the decision to arrest rather than otherwise diffuse the situation is at the discretion of the officer on the scene. Personal prejudices, like anti-immigrant or anti-Catholic sentiments, are more likely to play a role in such discretionary situations.

Even the conviction data from the 1850 Census must be interpreted with some care. Of the 27,000 convictions reported in the Census, over 17,000 were from just two states, New York and Massachusetts (U.S. Bureau of the Census 1854, 165). The large convict populations in these two states reflect two features: that crime is more common, per capita, in large cities than in smaller towns or rural areas; and these cities, being the two most common ports of entry, had large immigrant populations (Glaeser and Sacerdote 1996). So the disproportionate presence of the foreign-born in the conviction data reflects at least in part the disproportionate presence of the foreign-born in jurisdictions with high crime rates.

Any comparison of crime involvement by nativity must also take into account the disproportionate representation of immigrants in the demographic group with the highest crime rate: young males. Even though immigrants may have accounted for less than 15 percent of the population in 1850 , they accounted for a much higher fraction of males ages 18 to 25 . Because the age-crime profile is steep, failing to account for small differences in age distributions can lead to "aggregation bias," or to large but inaccurate calculations of differences in aggregated crime rates. Moehling and Piehl (2009) have shown that controlling for age effects greatly alters the comparison of native and foreign-born conviction rates in the early twentieth century. After the National Origins Quota Act of 1924 sharply reduced the inflow of new migrants, the immigrant population aged rapidly relative to the native-born population. Analysts at the time concluded that immigrants had a " 2 for 1 " advantage in incarceration. But using more detailed 
population data, Moehling and Piehl show that, for violent crimes in 1930, this advantage was wholly explained by the different age distributions.

As noted above, previous historical studies of crime in the $19^{\text {th }}$ century have found that immigrants were more prone to criminal behavior, but these studies did not adjust for the age and geographic distribution of immigrants (Lane 1979; Monkkonen 1989). More problematic

though, these studies focused on homicides and were forced to use surnames or unsystematically collected data on birthplace to infer immigrant status. The data used here afford an opportunity to study a wider range of criminal acts, including property crime and morals offenses, and to more accurately account for nativity. Exploiting these data will, therefore, provide a fuller appreciation of the connection between nativity and criminality in the mid-nineteenth century.

\section{Pennsylvania Prison Data}

Our approach to the question of immigration and criminality in the $19^{\text {th }}$ century is to restrict attention to a single jurisdiction, relying on administrative data on incarceration as well as data on the general population from the decennial federal censuses. We have data for the period 1830 to 1862 from Pennsylvania's two nineteenth-century state prisons: the Eastern Penitentiary in Philadelphia and the Western State Penitentiary in Pittsburgh. The extant records include the "Descriptive Registers" and the "Convict Docket" from the Eastern State Penitentiary and "Descriptive Registers" from the Western State Penitentiary. The ledgers include basic information about the convicts, including their names, ages, nativities, pre-incarceration occupations, the crimes for which they were incarcerated, sentence lengths, prior convictions, court and county of conviction, and the date of and reason for release (completion of sentence, executive pardon or commutation, or death). 
The Pennsylvania prison data hold several advantages over previously used information in the study of immigrant criminality. One advantage is that they are not limited to one type of crime. In the 30 years of data used here, convicted felons were incarcerated for more than 60 different crimes, ranging from abortion to vagrancy. The most common offenses, not surprisingly, were property crimes, notably burglary, larceny, and horse theft. Pennsylvania's prisons were also home to violent offenders - murderers, rapists and robbers - and to those convicted of various morals infractions, including bigamy, incest and fornication. These data offer an opportunity to study the connection between immigration and crime that covers the entire gamut of nineteenth-century criminal activity. Because we have data on the crimes that led to incarceration, we can examine whether immigrants and natives were convicted of different types of crimes or if one group was more likely to be involved in violent or property crimes. The main advantage of these data for our examination, however, is the systematically collected information on birthplace. We can determine immigration status directly and can even consider differences in experiences across immigrants from different source countries.

Despite the many advantages of the Pennsylvania prison data over those used in previous studies, the data are not without shortcomings. Prison incarcerations do not measure criminal activity per se. Rather, they reflect criminal activities that have been reported, investigated, prosecuted and resulted in a sentence of greater than 12 months. ${ }^{6}$ So although these data result from a sequence of choices, all jail or prison outcomes are filtered by the decision to arrest, to prosecute, to convict and to sentence. One advantage of our data compared to alternative sources, such as police arrest records or county jail records, is that prison incarcerations were not

\footnotetext{
${ }^{6}$ Under Pennsylvania law, the Eastern and Western State penitentiaries were not to accept criminals sentenced to less than 12 months incarceration; criminals sentenced to less than a year were to serve their time in a county jail. There were, however, some prisoners sent to the penitentiaries with shorter than 12month sentences. No explanation for these exceptions is given in the records.
} 
dominated by minor offenses, the prosecution of which varies greatly over time and space. State prison commitments capture more serious crimes and those to which more resources are put toward apprehension, prosecution, and conviction.

Like arrest records, however, incarceration data likely also reflect the impact of prejudice and discriminatory justice. The sequence of steps, and hence, the number of actors involved, in the process leading to a prison conviction reduced the effect of any one individual's personal prejudices on the outcome, but the widespread nativist sentiment during the period no doubt influenced jurors as well as judges. A criminal justice system biased against immigrants, though, potentially has several consequences, not all of which increase the immigrant incarceration rate. Much crime takes place within rather than across communities. The police may have been reluctant to investigate immigrant-on-immigrant crime. Moreover, fear of the police and the courts may have made immigrants less likely to report crimes. There is no way to identify definitively the impact of discriminatory justice in incarceration or any other type of crime data. Furthermore, biased application of law would be indistinguishable in crime data from other consequences of immigrant status, such as limited access to English translation or naiveté about the criminal justice process.

Because we have both the entry and release dates of prisoners, we can look not only at the flow of inmates into Pennsylvania state prisons but also at the Pennsylvania state prison population on specific dates. We can therefore look at the prison population around the dates of the federal censuses to compare the composition of the prison population to that of the nonincarcerated population of Pennsylvania. Moreover, we can use the prison and population data together to construct incarceration rates which control for age, gender, race, and even geographic distribution. 
In our analysis, we exclude those inmates who were referred from U.S. district courts to serve time in Pennsylvania prisons for violations of federal law. These 158 inmates (2.2 percent of the commitments) were convicted of federal crimes, such as mail theft or counterfeiting, rather than state crimes. At the time, there were few federal correctional facilities, so federal inmates were housed wherever federal officials could locate space (Friedman 1993:261-272). Our final sample then contains the universe of those sent to prison for violations of state criminal law. ${ }^{7}$

We combine the state prison data with data on the general population of Pennsylvania from the decennial federal population censuses taken from the Integrated Public Microdata Series (IPUMS). ${ }^{8}$ The census data allow us to test whether immigrants were disproportionately represented in Pennsylvania's state prisons and allow us to construct incarceration rates controlling for age, gender, race, and nativity. Despite the quality of the source data, we approach such comparisons and calculations with care. Even today, the federal census suffers from underenumeration; that is, some individuals are not counted in the census data. If underenumeration is uniform across the population, it would present few problems for our analysis. The calculated incarceration rates would be slightly higher than the "true" rates but we could still look at differences in rates across groups as evidence of systematic differences in behavior. The problem is that underenumeration in the census is potentially biased; the likelihood of being missed by the census varied across groups in the population. Immigrants, who may have faced language barriers, been fearful of government officials, and lived in crowded living quarters, may have been more likely to have been missed by census takers than

\footnotetext{
${ }^{7}$ It is possible that we miss observing some who were executed for their crimes. If someone were convicted of a capital crime and executed shortly thereafter in the local jurisdiction, they would not enter the prison data. We do observe some inmates who were executed after serving some time in one of the state prisons. We have searched for the universe of executions in order to identify the extent to which the prison data overlook the most serious convictions due to execution, but we have not located this information.

${ }^{8}$ The IPUMS data and supporting documentation is available on-line at: www.ipums.umn.edu.
} 
natives. Such biased underenumeration would bias our analysis toward finding that immigrants had higher incarceration rates than natives.

Several scholars have attempted to estimate the extent of underenumeration (Steckel 1991 provides a discussion), but two are particularly useful for our purposes because they specifically address biased underenumeration of blacks and immigrants. Using evidence of age

heaping, Sharpless and Shortridge (1975) estimate that African American underenumeration was about 10 percent greater than for whites. They also estimate 20 percent immigrant underenumeration. Furstenberg (1979) uses a rare recount in Philadelphia and estimates immigrant underenumeration to be between 5 and $20 \%$ higher than for native born whites. Because our objective is to compare immigrants in Pennsylvania's state prisons to immigrants in the state's general population, we need to be sensitive to the issue of biased underenumeration. In our results we use the lower and upper bound estimates (5 and 20\%) of the relative underenumeration of the foreign born to construct approximate error bounds around our point estimates of criminality.

\section{Immigrant Arrivals and Prison Commitments}

The first issue we address is the temporal patterns of immigrant arrivals and prison commitments. Figure 2 graphs all commitments to the Pennsylvania prisons as well as commitments for natives and the foreign born. Two features of the commitment series are easily explainable. First, commitments increase in the early 1830s not from increases in crime, but because the prisons themselves expanded. The original Western State Penitentiary opened in 1826, but the housing facilities were razed just seven years later when they were deemed inadequate. The Eastern State Penitentiary officially opened in 1829 with one operating 
cellblock. The second building opened in 1831; the seventh and final pre-Civil War cellblock opened in 1835 (Eastern State Penitentiary 2010). ${ }^{9}$ The volume of commitments remains relatively flat between 1835 and 1855 with, perhaps, a slight decline between 1840 and 1850 . Second, the sharp decline in commitments after 1860 likely reflects the effects of the Civil War. The war pulled large numbers of young men into military service, which expanded employment opportunities for those who did not enlist (Monkkonen 1981, 80; Gallman 1990, 271-3). ${ }^{10}$

The feature evident in Figure 2 that is less easily explained is the spike in prison admissions to well over 300 admissions per year in the late 1850s, and peak of nearly 400 in 1860. This spike seems to mirror the spike in immigration (nationwide), lagged by about 7 years. Several possible explanations could link these spikes. First, commitments may have lagged increased immigrant criminality due to long and variable lags in the dispensation of criminal justice. The lag, however, is far too long for the similar patterns in arrivals and commitments to be related. Nineteenth century criminal justice, just as in the twentieth century, was subject to procedural delays and continuances, but criminal cases were cleared from the docket at speeds that would astound modern Americans. If the accused was tried before a quarterly court, he might have been held in a county jail for as long as three months before trial, but grand juries worked with dispatch and the typical criminal trial lasted less than an hour. Moreover, if the jury found the defendant guilty they determined sentence length in the same

\footnotetext{
${ }^{9}$ Five additional cellblocks were constructed at the Eastern State Penitentiary between 1877 and 1911 and the Western State Penitentiary relocated to a new site in 1882, but these capacity increases occurred after the period we discuss. The Eastern State records also fail to reveal when the practice of solitary confinement was abandoned. It was officially ended in 1913, but it was known to have unofficially ended decades earlier. Given the rapid increase in commitments in the 1850 s, solitary confinement may have been abandoned much earlier than previously believed.

${ }^{10}$ Philadelphia did not experience the violent riots in the early years of the war that plagued other large Northern cities. Gallman (1990) attributes this relative peace to the city's mayor, Alexander Henry, and his efforts starting in the late 1850s to improve the police force (p. 192).
} 
sitting. Convicted felons arrived at the prison just days after their court date (Rice 1996, Langbein 1978).

A more plausible connection hinges on different criminal involvement by age at immigration. If those who initiated the crossing of the Atlantic have low crime rates (due to fear of the government or special positive selection), those who were young at the time of immigration may appear more like second generation immigrants or natives. Thus, the lag may represent the aging into the crime prone years of the "1.5 generation." Unfortunately, the Pennsylvania state prison data do not provide information on the age at immigration so we cannot test this hypothesis directly, but the data provided in Figure 2 (the commitment diagram) are not fully inconsistent with the hypothesis. There is an increase in foreign-born commitments between 1848 and 1856 (relative to the trend between 1832 and 1847), which may be due to an increased recent immigrant pool or the entry of young-age immigrants into the prime offending years.

But Figure 2 reveals an interesting feature of annual commitments. There is a modest increase in foreign-born commitments between 1856 and 1860, but it pales in comparison to the increase in native-born commitments over the same interval. The increase in commitments after 1856 is due to increased commitments of nonviolent offenders and may be due, in part, to the Panic of 1857. Although early nineteenth-century financial panics are not believed to have notable employment or wage effects, the series is consistent with crime as an anticyclical activity (Calomiris and Schweikart 1991). ${ }^{11}$ While the time patterns are consistent with the panic story, it is not immediately obvious is why the 1857 panic would have more pronounced effects that the

${ }^{11}$ Fishlow (1965) argues that a recession began in 1856 caused, in part, by a decline in immigrant inflows to the Old Northwest, which had previously boosted land prices and fueled a railroad boom. The recession was transmitted to eastern markets with the failure of Ohio Life and Trust, which led to a run on eastern money center banks. 
1839 panic and why the downturn would have more pronounced effects on the native born than on the foreign born. Some evidence suggests that the pre-prison economic circumstances of inmates declined for natives during the panic years. Using the socioeconomic index (SEI) for occupation titles developed by Reiss et al. (1961) using average educational attainment and earnings for occupations listed in early twentieth century censuses, the average SEI value of native-born commitments declined from 17.9 between 1850 and 1856 to 15.8 between 1857 and 1860. Among foreign-born commitments, the average SEI value declined from 17.7 in the prepanic years to 16.6 in the post-panic years. These findings need to be interpreted with some care due to the fact that the index is based on a ranking of occupations 50 years after the panic. Nonetheless, the statistically significant decline in the SEI value of the native-born suggests that the average occupation declined from a puddler in an iron foundry to a cook or waiter, which may be an economically meaningful change. That the change in the average occupation of new commitments was not significantly different for the foreign born suggests that the post-panic recession may have had a more detrimental effect on native-born than foreign-born workers. But these interpretations are tentative in light of how little economic historians know about the labor market effects of early $19^{\text {th }}$ century recessions.

\section{Aggregate Incarceration Experience: Immigrants and Natives}

One issue we can address directly with the Pennsylvania prison data is whether immigrants were more likely than natives to be incarcerated. We begin our analysis by comparing the percent foreign born within the prison population to that of the general population on the dates of the federal censuses. To increase sample sizes and gain some statistical power in the prison data, we take a snapshot of the prison population on June 1 in each of the five years 
surrounding the Census year. ${ }^{12}$ That is, data reported for 1840 reflect the composition of the two Pennsylvania prisons on June 1 of 1838, 1839, 1840, 1841, and 1842. Taking five years rather than a single year gives us sufficient sample size for later analyses by type of crime and should mitigate any short-term idiosyncratic behavior in crime or sentencing. ${ }^{13}$

Table 1 presents these numbers. In 1840, 18.7 percent of Pennsylvania prison population was foreign born; a decade later it had increased to 26.4 percent and further rose to 27.4 percent in 1860. The wave in new immigrant arrivals evident in Figure 1 was accompanied by an increase in the foreign-born prison population. Moreover, the foreign born accounted for a much larger fraction of the prison population than they did of the general population in Pennsylvania during this period. Because the 1840 Census did not collect data on birthplace, we do not know the percentage of foreign born in the general population in that year, but the foreign born accounted for only 13.1 percent of Pennsylvania's population in 1850 and 15.0 percent in 1860 . Even if the relative underenumeration of immigrants in the census reached the 20 percent upper bound, the foreign born still accounted for 18 percent of the non-incarcerated population in Pennsylvania in 1860 , compared to 27.4 percent of those in prison.

A simple comparison of the fraction foreign born in the prison population to that of the population overall may be misleading. The age distribution of the prison population differs greatly from the age distribution of the general population, which makes immigrants appear more prone to criminal behavior than they really are. The top panel of Figure 3 presents the age distribution of the Pennsylvania state prison population in 1860. Over 60 percent of the prison

\footnotetext{
${ }^{12}$ Note that these snapshots represent the "stock" of inmates around the Census years. Therefore the numbers are not directly comparable to those in Figure 1, which plots the flow of commitments into prison.

${ }^{13}$ For the broader categories of interest, the five-year averages do not differ greatly from the data constructed from the prison population on the census dates: June 1, 1840, June 1, 1850, and June 1, 1860. We use five-year averages to deal with the "small cell" problem that arises once we start cutting the data by multiple characteristics like crime type, nativity, and age.
} 
population was between the ages of 18 and 29 and over 85 percent was between the ages of 18 and 44. The bottom panel of Figure 3 presents the age distributions of the native- and foreignborn populations constructed from the IPUMS sample of the 1860 Census. Almost half of the native population was under the age of 16 , a group almost absent from the prison rolls, and only 35 percent were in the prime crime ages of 18 to 44 . In contrast, less than 10 percent of the foreign born population were children and almost 65 percent were between the ages of 18 and 44. In other words, the foreign born accounted for a much larger fraction of the population in the age range most at risk for incarceration than of the overall population. Returning to Table 1 , if we compare the percent foreign born in prison to that of the general population ages 18 to 44 , the disparity shrinks; in 1860, immigrants accounted for 27.4 percent of the prison population but 24.5 percent of the general population ages 18 to 44 . If actual immigrant underenumeration approached the 5 percent lower-bound estimates, any difference between the fraction foreign born in prison and in the general population is practically eliminated.

The immigrant population during this period also had a higher fraction male than female. If we compare the fraction foreign born among male prisoners to that of Pennsylvania's male population ages 18 to 44 , the gap between the prison population and the general population narrows even further: 27.1 percent to 25.4 percent in 1860 . Interestingly, limiting the comparison to just females has the opposite effect. Foreign-born women accounted for 37.1 percent of the female prison population in 1860 but only 23.6 percent of the Pennsylvania's female population in the relevant $18-44$ age range. It is important to note, however, that very few women were sentenced to the Pennsylvania state prisons during this period; for each yearly snapshot, there are only about 20 female prisoners. Women, then as now, are much less likely to be convicted of crimes and when they are, it tends to be for less serious offenses than men, which 
result in short sentences typically in local jails or other facilities. The group of women found in the state prisons should be viewed as fairly exceptional, even among female criminals. It is notable, though, that the foreign born are disproportionately represented in this exceptional group.

Adjusting for age and gender greatly narrows the observed gap between the imprisoned foreign born and those in the general population, but if we adjust for race the gap widens. Pennsylvania had a small, but not insignificant, black and mixed-race population in the pre-Civil War period and this population was disproportionately represented in the state prisons. Immigrants during this period were, for the most part, white. If the comparison is restricted to white males ages 18 to 44 , the disparity between the percent foreign born in the prison and general population increases. In 1860, the foreign born accounted for 30.8 percent of the white male prison population but only 25.8 of the prime-age white males in the general population, a disparity that only disappears if the highest estimate for potential underenumeration bias (20\%) is used.

We need to ask whether a study of nativity effects on incarceration, and crime more generally, is correct to focus on the white population? Modern research on immigration and crime does not restrict itself to any one racial group, but today's immigrants are of all races. In the nineteenth century, the discussion of immigration and crime concentrated on the differences by nativity within the white population. Although there were West Indian immigrant communities in some North American cities, they were quite small. Northern cities were not attractive to West Indian migrants because existing African American communities in these cities, where most immigrants made their homes, were small. Black criminality, too, was viewed as a distinct phenomenon from crime within the immigrant communities. Finally, Philadelphia 
had the largest free African American population of any non-southern US city, so its experience (and that of Pennsylvania more generally) may not be indicative of the racial composition of crime in nonslave states. Any generalizations based on Pennsylvania's black experience must be drawn with caution.

Table 2 reports incarceration rates (per 100,000) by race, gender, and nativity within the crime-prone 18-44 year age category. The first thing to note is just how high the incarceration rates are for African American (black and mulatto) males; they exceed 800 per 100,000, making them seven to eight times the rate for any other studied group. ${ }^{14}$ The exceptional African American incarceration rates are potentially inflated by census underenumeration, but no plausible value for the underenumeration bias can account for the disparity. It seems reasonable to conclude that African Americans were much more likely to be incarcerated than were white men. ${ }^{15}$ Because the black experience was so different than the native-born white experience, including blacks with native whites makes the foreign-born incarceration experience appear more favorable. In 1860, for instance, the calculated incarceration rate for white foreign-born males is 121 and that of native males is very close (112). If we restrict the comparison to white males, the nativity gap is much larger: 94 white native-born incarcerations per 100,000 population versus 121 foreign-born per 100,000 in 1860 .

In most of what follows we exclude African Americans from the analysis, not because their experience is unworthy of study, but rather because it is so markedly different from the white experience that it merits study on its own terms. This focus also allows us to situate our

\footnotetext{
${ }^{14}$ Current incarceration rates are higher, but similarly disproportionate. White men are incarcerated at rate of 487 per 100,000 and African American men at a rate of 3,161 per 100,000, for a ratio of over 6 to 1 (Sabol et al. 2009).

${ }^{15} \mathrm{Du}$ Bois (1899) found comparable racial incarceration differences in late nineteenth-century Philadelphia.
} 
results better into the historical debate about immigration and crime as well as to isolate the effect of nativity from that of race. We further restrict ourselves to the incarceration patterns of males as the rates of incarceration of women in Pennsylvania's prisons were quite low (4 per 100,000 in 1850 and 1860).

\section{Exploring the Differences in Immigrant and Native Incarceration}

The aggregate incarceration rates in Table 2 indicate that among prime-age white males, immigrants were much more likely to be in a state prison than were natives in both 1850 and 1860. Even if we assumed the upper-bound estimate (20 percent) for the relative underenumeration of immigrants, the incarceration rate for immigrants would be substantively higher than that of natives (100 vs. 94). These aggregate rates, however, control only crudely for differences in the age distributions of the foreign-born and natives. As shown in Figure 3, the age-crime curve is rather steep; 60 percent of all prisoners in 1860 were between the ages of 18 and 29, and this age group comprised a larger fraction of the immigrant population than the native-born population.

In Table 3, we present the incarceration rates for immigrants and natives by more narrowly defined age groups. Incarceration rates are minimal for those under 16, and quite low for $16-17$ year olds and those over age $45 .{ }^{16}$ For both immigrants and the native born, the ageincarceration rate profiles exhibit the expected pattern, peaking in the early 20 s then slowly falling thereafter. Note, however, that the incarceration rates for immigrants were much higher

\footnotetext{
${ }^{16}$ At the time, common law held that those aged 14 and older could be sent to state prison. (In our data, there are several inmates younger than 14.) Separate juvenile jurisdiction came later. The first juvenile court was started in Illinois in 1899. We include all observations in the aggregate rates, including children and those with age missing.
} 
than those for natives for every age group 18 and older. The nativity differences are particularly striking in 1850 when for many age groups the foreign-born rate was twice that of the natives. Between 1850 and 1860, the incarceration rates for men between 18 and 29 grew dramatically for both nativity groups. In general, the rates increased more for natives than the foreign-born, but the foreign born still had substantially higher incarceration rates. At every age, immigrants were more likely than natives to be in a state prison.

As discussed earlier, the story of immigration has long been intertwined with the development of cities. Immigrants were concentrated in large cities where reported crime rates were higher, perhaps because criminal opportunities and activities were greater in these areas or perhaps because there was greater law enforcement in these areas. In Tables 4 and 5 we investigate the hypothesis that urban and rural counties had different patterns of both immigration and incarceration. We define "urban" as Philadelphia and Allegheny counties, with the rest of the state as "rural." The first interesting fact is that while nearly half of the population in the urban counties was foreign born, about 35 percent of prisoners convicted from urban courts were foreign born. In the rural counties, 15 to 17 percent of the general population was foreign born in 1850 and 1860, whereas nearly one-third of prisoners from rural areas were foreign born.

In Table 5 we consider finer age-specific incarceration rates (comparable to those in Table 3) for the urban and rural counties to explore age-crime profile in greater detail. When we parse the data in this way, several remarkable features of nineteenth-century criminal sentencing appear. First, the disproportionate representation of the foreign-born young adults in Pennsylvania's prisons is almost entirely a rural, not an urban phenomenon. Among men in their twenties in 1850, the rural foreign born were incarcerated at twice the rate of the native born. 
Among men between 35 and 44 years old, the rural foreign-born were incarcerated at three times or more the rate of the native born. The disparities narrow somewhat by 1860 , but the rural foreign born are about twice as likely as rural native-born men in the same age group to be incarcerated. Second, among those men in urban counties in both 1850 and 1860, the foreign born generally have lower incarceration rates than natives. In 1860 in particular, the incarceration rates for the foreign born are sometimes appreciably lower, on the order of 50-60 percent of the native rates.

Third, when we compare incarceration rates for urban and rural areas in 1850 , the incarceration rates for native-born men are much higher for urban counties than for rural ones. In 1850 the incarceration rate for urban native-born teens and adult men is two to three times the rate of rural native-born males in the same age group. Although incarceration rates decline with age for both urban and rural native-born men, the urban offending rate exceeds the rural offending rate well past the peak offending years. This result is consistent with Glaeser and Sacerdote's (1999) explanation for "why is there more crime in cities?" Cities afford more opportunities for crime, often offer greater rewards for criminal activity, and the anonymity of cities reduces apprehension probabilities relative to rural areas. ${ }^{17}$

It is striking how different the urban-rural comparison is for natives and the foreign born. For immigrants, the incarceration rates are on the same order of magnitude in rural and urban settings. This discrepancy suggests that the phenomena of immigrant and native crime are somewhat different. Recall that our study measures crime from prison records, which include serious felonies. We know from previous studies that immigrants were arrested at much higher rates than native-born. The population of arrests will be dominated by more trivial offenses.

\footnotetext{
${ }^{17}$ While the pattern of positive correlation between crime rates and city population was longstanding, the dramatic crime declines over the past decade or so have been largest in the largest cities, so that the gradient is no longer as strong as when evaluated by Glaeser and Sacerdote (1999).
} 
The relative under-representation of the urban foreign born in prisons (especially relative to the arrest figures cited earlier, in which the foreign born were the vast majority) suggests that their criminal experience was, as Handlin (1959, p. 134) characterized it, more the consequence of poverty and a failure to comply with the barely understood rules of a new society than "deliberate" wrongdoing by men "at war with society." This interpretation is consistent with Moehling and Piehl's (2009) finding, using data from 50 years later, that the foreign born had high rates of prison commitments for minor crimes, and that these high rates continued well into middle age.

In summary, Table 5 reveals that in rural counties, the foreign born had much higher incarceration rates than the native born. By 1860 , the nativity gap is so large that the rural foreign-born incarceration rates are the same order of magnitude or even higher than those for urban foreign born. For natives, the rural rates are generally half the size of those of the urban native born. Clearly the interaction of nativity with urban residence explains much of the observed aggregate differentials in incarceration rates. While it is well beyond the scope of this paper, it would be interesting to know whether this urban-rural differential was unique to nineteenth century Pennsylvania or whether it is a generalizable result. It may explain why, as Martinez and Lee (2000, p.495) note, "the major finding of a century of research on immigration and crime is that immigrants ... nearly always exhibit lower crime rates than native groups." This major finding may exist because studies tend to investigate urban crime. Dense ethnic neighborhoods in urban places may provide cultural refuge for new immigrants not found in rural places.

In Tables 6 and 7, we disaggregate along a different dimension, specifically, offense type. Table 6 shows the offense distribution by nativity. Here the data are used somewhat differently 
in order to produce larger sample sizes, which afford a detailed accounting. The statistics in Table 6 are calculated from all commitments to prison over the period 1830-1862. Relative to the point-in-time snapshots reported earlier, commitment data will emphasize crimes with shorter terms of incarceration. Using this measure, 72 percent of the foreign-born inmates were committed for property offenses as were 80 percent of the natives. Nearly 10 percent of the foreign born were committed for homicide, twice the proportion as among the natives. Note that the offense information is not neatly categorized. Some records indicate simply "felony" or "misdemeanor" without designating the type of underlying offense, but the proportion of unspecified crimes is too small to substantially alter the native-foreign relative commitment rates unless they were systematically applied to only natives or foreign born. The bottom line is that, among those committed, immigrants were more likely to have engaged in a violent act.

Table 7 returns to the incarceration rate measure, grouping crimes into "violent" (homicide, person), "property," and "other" (public order and moral offenses along with misdemeanor and otherwise uncategorized offenses). Here we see that the foreign born consistently have higher incarceration rates for violent crimes, but from 1850 to 1860 the natives largely closed the gap with the foreign born for property offenses. In the next section we look at whether there are different crime patterns across particular immigrant groups.

\section{Variation across Immigrant Groups: British, Irish, and Germans}

One "major finding" of research into immigration and crime in the twentieth century is that immigrants exhibit lower rates of criminality than natives. A second is that there is wide variation in criminality across broadly defined immigrant groups (Martinez and Lee 2000). That is, "Asian" criminality may not be a meaningful measure if offending rates differ between 
Chinese, Japanese, Vietnamese and Filipino immigrants. In the same way, immigrant criminality may not be a meaningful idea for a study of the nineteenth century if offending rates or types of crime committed differed across different nationalities. In this section, we consider commitment and incarceration rates across the three largest mid-nineteenth century immigrant groups, namely, the Irish, Germans and Britons. Our use of these three groups is based on two criteria. First, we can think of the British as "old" immigrants in that they represented the largest and longest running nationality of immigrants over the very long term between settlement in 1607 Jamestown and the mid-nineteenth century. While there was a long tradition of both Irish and German immigration, the immigrants from these countries changed dramatically at mid-century. Before the potato famine, most Irish immigrants were reasonably well-to-do Protestants. After the famine, the majority were poor Catholics (Handlin 1959; McCaffrey 1976; Farrell 2003; Ignatiev 1995 disputes this). Similarly, the political and social upheaval in mid-century Germany changed the nature of German immigration. Second, we investigate these three groups for the very practical reason that they are the most commonly observed immigrants in the prison data and afford large enough sample sizes to make meaningful comparisons.

In Table 8 we compare the proportions of the three principal immigrant groups in the prison population to those in the general population of 18 to 44 year-old men. Two features stand out. First, the proportions of German and British immigrants in the prison population exceed the proportion of these two groups in the overall population in both 1850 and 1860, though the German prison overrepresentation is notably larger than for British immigrants. Second, despite deep contemporary social concerns with the big wave of poor Irish immigrants at mid-century, the prisons were not overrun with Irish immigrants. The proportion Irish in the prison mirrors the proportion Irish in the population. This, despite the contemporary diarist George Templeton 
Strong's now infamous quote that "our Celtic fellow citizens are almost as remote from us in temperament and constitution as the Chinese" (quoted in Wittke 1956, p. 40). It turns out, at least as far as their overall participation in serious crime is concerned, that the "new" Irish were not very remote from the native born.

Table 9 reports incarceration rates for the three principal immigrant groups using the finer age categories used in Table 5. It is difficult to draw any generalizations about differential criminality across the three immigrant groups in 1850. At some ages, German and British immigrants are more crime prone than the Irish; at other others they are less. The only systematic difference appears to be a somewhat higher criminal propensity among German immigrants age 30 and above. In 1860, German incarceration rates continued to exceed those of the Irish and the British in most age groups. More noteworthy, perhaps, are the rising rates of criminality among the Irish and the Germans between 1850 and 1860. Except for those 19 years and below, incarceration rates for these two groups rose over the decade, sometimes dramatically. British immigrants display a declining tendency toward incarceration over the decade, especially for those 35 years and older. This may reflect the greater ease with which the British assimilated into American society, but assigning any cause to such changes remains speculative without further research.

In Table 10, we again consider differential offending by narrow types of crime across the three groups. It may have been the Irish immigrants' greater propensity toward violent criminal acts - homicide and person crimes - that moved Strong to consider the Irish a breed apart. The Irish were nearly five times more likely to be committed for homicide than Germans or Britons. The Irish were nearly twice as likely as the Germans to be committed for a crime against persons (assault mostly). The image of the young Irish tough popularized in Martin Scorsese's Gangs of 
New York may have been realistic if not fully accurate. The evidence lends further support to McCaffrey's (1976) contention that the Irish were the law and order problem of the 1850s.

Table 11 reports incarceration rates (per 100,000) for the Irish, Germans and British and reproduces the values of the native born (from Table 7) for comparative purposes. In 1850 immigrants were incarcerated at much higher rates than the native born for violent crime, generally at two to three times the native-born rate. By 1860 native-born violent incarceration rates had doubled over their 1850 value, but they still remained lower than for immigrants. Violence, or at least incarcerations for violent crimes, more than doubled for the Irish, reaching an astounding 55 per 100,000 in the years around 1860. Differences in property and other crimes pale compared to Irish violence, but it is notable that the rate of property incarcerations among German immigrants is substantially higher than for the Irish or the native born. Thus, the snapshot of incarcerations around the census years yields a conclusion similar to inflow of commitments. The Irish were violent; at the very least, they were convicted for violent acts at a much higher rate than any other group, whether immigrant or native born.

\section{Concluding Remarks}

Our analysis of prison data from Pennsylvania during the middle of the $19^{\text {th }}$ century provides some insight into the empirical relationship between immigration and crime during the first major wave of immigration, a time when concern about immigrant criminality was extremely high. We find that adjusting for age and gender greatly narrows the observed gap in incarceration rates of the foreign- and native-born. Adjusting for race broadens the gap. In 1850 and especially in 1860, incarceration rates for immigrants were much higher for immigrants than for natives for every age group 18 and older. Different patterns by urban/rural geography are 
particularly striking. Immigrants were concentrated in the urban counties of Philadelphia and Allegheny where reported crime rates were higher. Within rural counties, the foreign born had much higher incarceration rates than the native born. By 1860 , the nativity gap is so large that the rural foreign-born incarceration rates are the same order of magnitude or even higher than those for urban foreign born. For natives, the rural rates are generally half the size of those of urban native born. The interaction of nativity with urban residence explains much of the observed aggregate differentials in incarceration rates. Finally, we found that the foreign born, especially the Irish, consistently have higher incarceration rates for violent crimes, but from 1850 to 1860 the natives largely closed the gap with the foreign born for property offenses.

The conclusions for this analysis of prison data is largely in accord with the findings of Monkkonen and Lane regarding high levels of participation of immigrants in urban violent crime during this period of American history. But in contrast to these scholars, the results from using a broader measure of criminality reveal little gap between immigrants and natives for nonviolent crime. In addition, we have uncovered a dramatic difference between how immigrants fared in cities and rural areas. 


\section{References}

Berger, H. and M. Spoerer. 2001. "Economic Crises and the European Revolutions of 1848." Journal of Economic History 61(2): 293-326.

Brown, M. C. and B. D. Warner. 1995. "The Political Threat of Immigrant Groups and Police Aggressiveness in 1900." Pp. 82-98 in Ethnicity, Race, and Crime: Perspectives across Time and Place, edited by D. F. Hawkins. Albany: State University of New York Press.

Bursik, R.J. 2006. "Rethinking the Chicago School of Criminology: A New Era of Immigration.” Pp. 2035 in Immigration and Crime, edited by R. Martinez, Jr. and A. Valenzuela, Jr. New York: New York University Press.

Calomiris, C. and L. Schweikart. 1991. "The Panic of 1857: Origins, Transmission, and Containment." Journal of Economic History 51(4): 807-834.

Carter, Susan B. and Richard Sutch. 2006 "U.S. Immigrants and Emigrants, 1820-1998," Table Ad1-2, in Historical Statistics of the United States, Earliest Times to the Present: Millennial Edition, edited by Susan B. Carter, Scott Sigmund Gartner, Michael R. Haines, Alan L. Olmstead, Richard Sutch, and Gavin Wright. New York: Cambridge University Press.

Christian Watchman. 1847. "Pauper Immigration.” July 2.

Claghorn, K. H. 1971. The Immigrant's Day in Court, Vol. 9 of Americanization Studies, edited by W. S. Bernard. Montclair, NJ: Patterson Smith (original publication 1923 by Harper \& Brothers).

Du Bois, W. E. B. 1899. The Philadelphia Negro: A Social Study. Philadelphia: University of Pennsylvania.

Eastern State Penitentiary. 1829-1857. Population Records, Descriptive Register. Record Group 15. Records of the Department of Justice. Harrisburg: Pennsylvania State Library.

Eastern State Penitentiary. 2010. http://www.easternstate.org/history/

Eliott, J. H. 1869. "The Increase of Material Prosperity and of Moral Agents, Compared with the State of Crime and Pauperism." Merchants' Magazine and Commercial Review 61 (October), 339-365.

Farrell, H. F. 2003. The Irish in New Orleans, Colonial Period to 1860. Unpublished M.A. thesis: University of New Orleans.

Fishlow, A. 1965. American Railroads and the Transformation of the Ante-Bellum Economy. Cambridge, Mass.: Harvard University Press.

Friedman, Lawrence M. 1993. Crime and Punishment in American History, Basic Books.

Furstenberg, F. F. 1979. "What Happened When the Census Was Redone: An Analysis of the Recount of 1870 in Philadelphia." Sociology and Social Research 63: 475-505.

Gallman, J. M. 1990. Mastering Wartime: A Social History of Philadelphia during the Civil War. Cambridge: Cambridge University Press. 
Glaeser, E. L. and B. Sacerdote. 1999. "Why is There More Crime in Cities?” Journal of Political Economy 107(6):

Goldin, C. 1994. "The Political Economy of Immigration Restriction in the United States, 1890-1921." Pp. 223-57 in The Regulated Economy: A Historical Approach to Political Economy, edited by C. Goldin and G. Libecap. Chicago: University of Chicago Press.

Gurr, T. R. 1989. "Historical Trends in Violent Crime: Europe and the United States." Pp. 21-54 in Violence in America. Volume 1: The History of Crime, edited by T. R. Gurr. New York: Sage Publications.

Haines, M. R. 2006. "Native-born white population, by sex and age: 1870-1970," Table Aa1922-1973 and "Foreign-born white population, by sex and age: 1870-1970," Table Aa1974-2025. In Historical Statistics of the United States, Earliest Times to the Present: Millennial Edition, edited by S. B. Carter, S. S. Gartner, M. R. Haines, A. L. Olmstead, R. Sutch, and G. Wright. New York: Cambridge University Press.

Handlin, O. 1959. Boston's Immigrants: A Study in Acculturation. Revised edition. Cambridge, Mass.: Belknap Press of Harvard University Press.

Ignatiev, N. 1995. How the Irish became White. New York and London: Routledge.

Jones, M. A. 1980. “Immigration.” Pp. 1068-86 in Encyclopedia of American Economic History, edited by G. Porter. New York: Scribner.

Jones, M. A. 1976. Destination America. London: Widenfeld and Nicolson.

Jones, M. A. 1974. American Immigration. Chicago: University of Chicago Press.

Lane, Roger. 1979. Violent Death in the City. Harvard University Press.

Lane, Roger. 1989. "On the Social Meaning of Homicide Trends in America." pp. 55-79 in Violence in America. Volume 1: The History of Crime, edited by T. R. Gurr. New York: Sage Publications.

Langbein, John H. 1978. "The Criminal Trial before the Lawyers." University of Chicago Law Review 45(2): 263-316.

Little, Craig B. 1991. "The Criminal Courts in 'Young America': Bucks County, Pennsylvania, 18201860, with Some Comparisons to Massachusetts and South Carolina," Social Science History 15:457-478.

Maltz, M. D. 1977. “Crime Statistics: A Historical Perspective.” Crime and Delinquency 23:32-50.

Martinez, R. Jr. and M.T. Lee. 2000. “On Immigration and Crime," pp. 485-524. In The Nature of Crime: Continuity and Change. Edited by Gary LaFree. Washington, D.C.: National Institute of Justice.

Martinez, R. Jr., A. L. Nielsen, and M.T. Lee. 2003. "Reconsidering the Marielito Legacy:

Race/Ethnicity, Nativity, and Homicide Motives.” Social Science Quarterly 84(2): 397-411.

McCaffrey, L. J. 1976. The Irish Diaspora in America. Bloomington: Indiana University Press. 
Moehling, Carolyn and Anne Morrison Piehl 2009. "Immigration, Crime, and Incarceration in Early Twentieth Century America," Demography, 46(4): 739-763.

Monkkonen, E. H. 1981. Police in Urban America, 1860-1910. Cambridge: Cambridge University Press.

Monkkonen, E. H. 1989. “Diverging Homicide Rates: England and the United States, 1850-1875.” Pp. 80-101 in Violence in America. Volume 1: The History of Crime, edited by T. R. Gurr. New York: Sage Publications.

National Commission on Law Observance and Enforcement. 1931. Report on Crime and the Foreign Born, Report number 10. Washington DC: Government Printing Office.

Naylor, T. J. 1979. Criminals, Crime and Punishment in Philadelphia, 1866-1916. Unpublished Ph.D. dissertation, University of Pennsylvania.

New York Daily Times. 1853. “Imported Crime,” September 24.

New York Times. 1858. "Foreign Criminals in New York, " February 22.

Reiss, A.J., O.D Duncan, P.K. Hatt, and C. C. North. 1961. Occupations and Social Status. New York: Glencoe Press.

Rice, J. D. 1996. “The Criminal Trial Before and After the Lawyers: Authority, Law, and Culture in Maryland Jury Trials, 1681-1837.” American Journal of Legal History 40(4): 455-475.

Ruggles, S., M. Sobek T. Alexander, C.A. Fitch, R. Goeken, P.K. Hall, M. King, and C. Ronnander. 2008. Integrated Public Use Microdata Series: Version 4.0 [Machine-readable database]. Minneapolis, MN: Minnesota Population Center [producer and distributor]. Available online at http://usa.ipums.org/usa/.

Sabol, William J., Heather C. West, and Matthew Cooper. 2009. Prisoners in 2008, Bureau of Justice Statistics Bulletin, NCJ-228417.

Sellin, Thorsten. 1938. Culture, Conflict, and Crime, Social Science Research Council, Bulletin 41, New York.

Sharpless, John B. and Ray M. Shortridge. 1975. "Biased Underenumeration in Census Manuscripts: Methodological Implications.” Journal of Urban History 1 (August): 409-439.

Steckel, Richard H. 1991. "The Quality of Census Data for Historical Inquiry: A Research Agenda." Social Science History 15 (Winter 1991): 579-599.

Taft, D. R. 1933. "Does Immigration Increase Crime?" Social Forces, 12 (October): 69-77.

Thomas, Brinley. 1954. Migration and Economic Growth. Cambridge: Cambridge University Press.

Thomas, W. I. with R. E. Park and H. A. Miller. 1971. Old World Traits Transplanted, Vol. 3 of Americanization Studies edited by W. S. Bernard. Montclair, NJ: Patterson Smith (original publication 1921 by Harper \& Brothers). 
U.S. Bureau of the Census. 1853. The Seventh Census: Report of the Superintendent of the Census for December 1, 1852. Washington: Robert Armstrong, Printer.

U.S. Bureau of the Census. 1854. Statistical View of the United States: Compendium of the Seventh Census. Washington: Beverley Tucker, Senate Printer.

U.S. Senate. 1970a. Reports of the Immigration Commission. Volume 1: Abstracts of Reports of the Immigration Commission. With an Introduction by Oscar Handlin. New York: Arno Press (original publication 1911 by Government Printing Office).

U.S. Senate. 1970b. Reports of the Immigration Commission. Volume 36: Immigration and Crime. New York: Arno Press (original publication 1911 by Government Printing Office).

U.S. Senate. 1970c. Reports of the Immigration Commission. Volume 34: Immigrants as Charity Seekers. New York: Arno Press (original publication 1911 by Government Printing Office).

Western State Penitentiary. 1826-1876. Convict Docket \& Descriptive Register. Record Group 15. Records of the Department of Justice. Harrisburg: Pennsylvania State Library.

Wittke, C. 1956. The Irish in America. Baton Rouge: Louisiana State University Press. 
Figure 1: Immigrant Arrivals to the United States 1830-1862

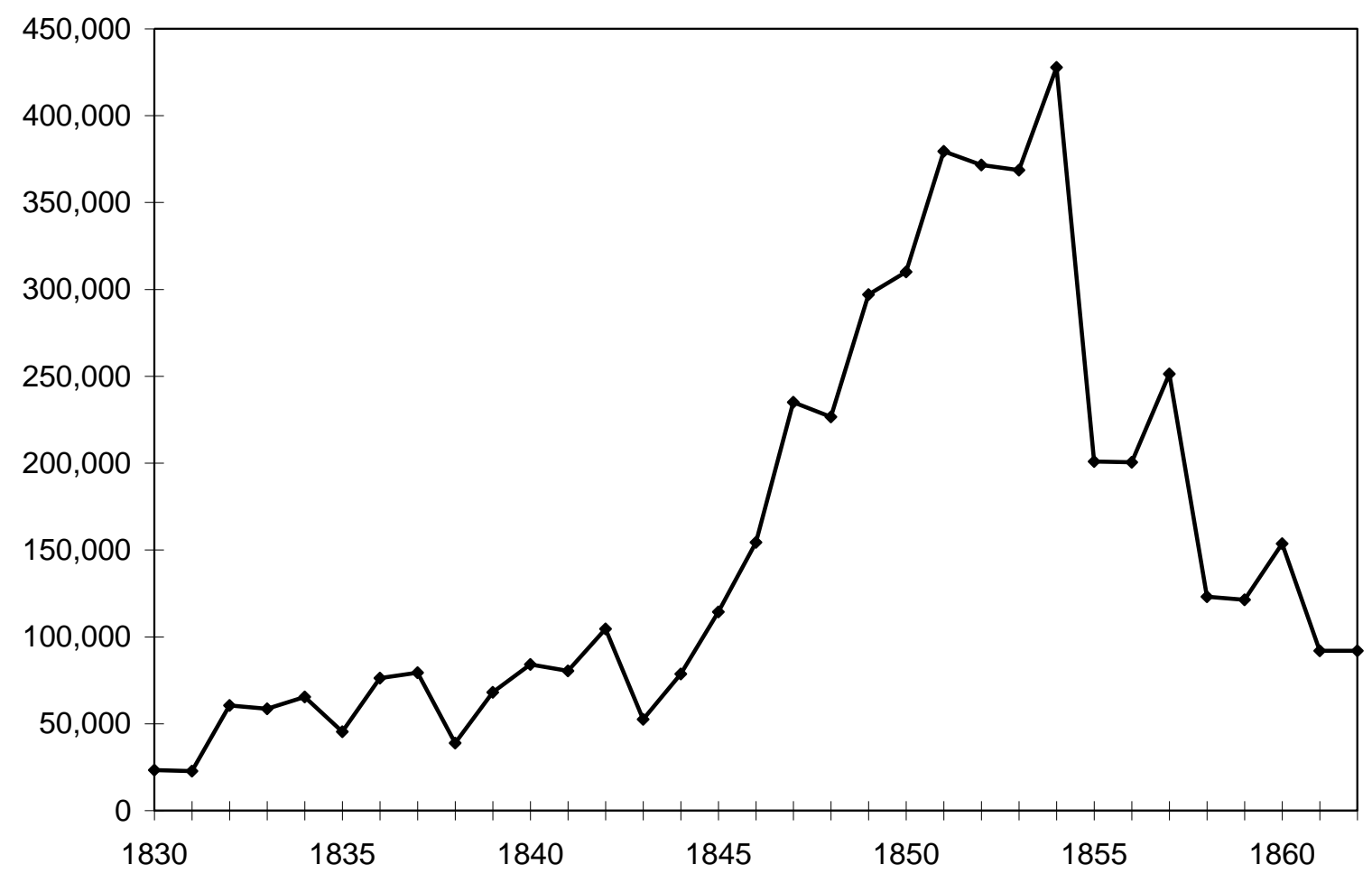

Source: Carter and Sutch (2006). 
Figure 2: Commitments to Pennsylvania State Prisons, 1830-1862

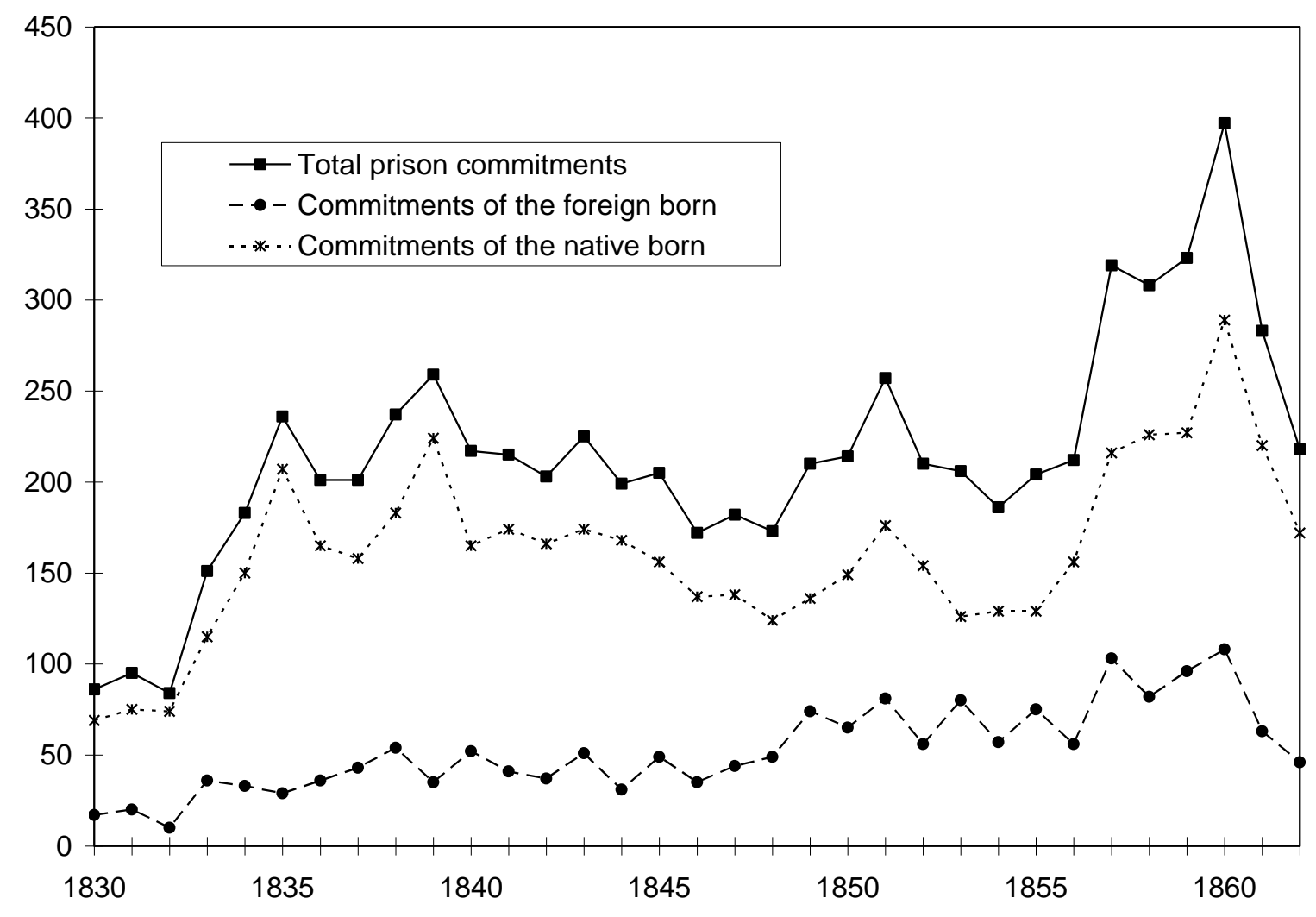

Source: Pennsylvania State Prison data. See text for details. 
Figure 3: Age Distributions, 1860

Panel A: Pennsylvania Prison Population

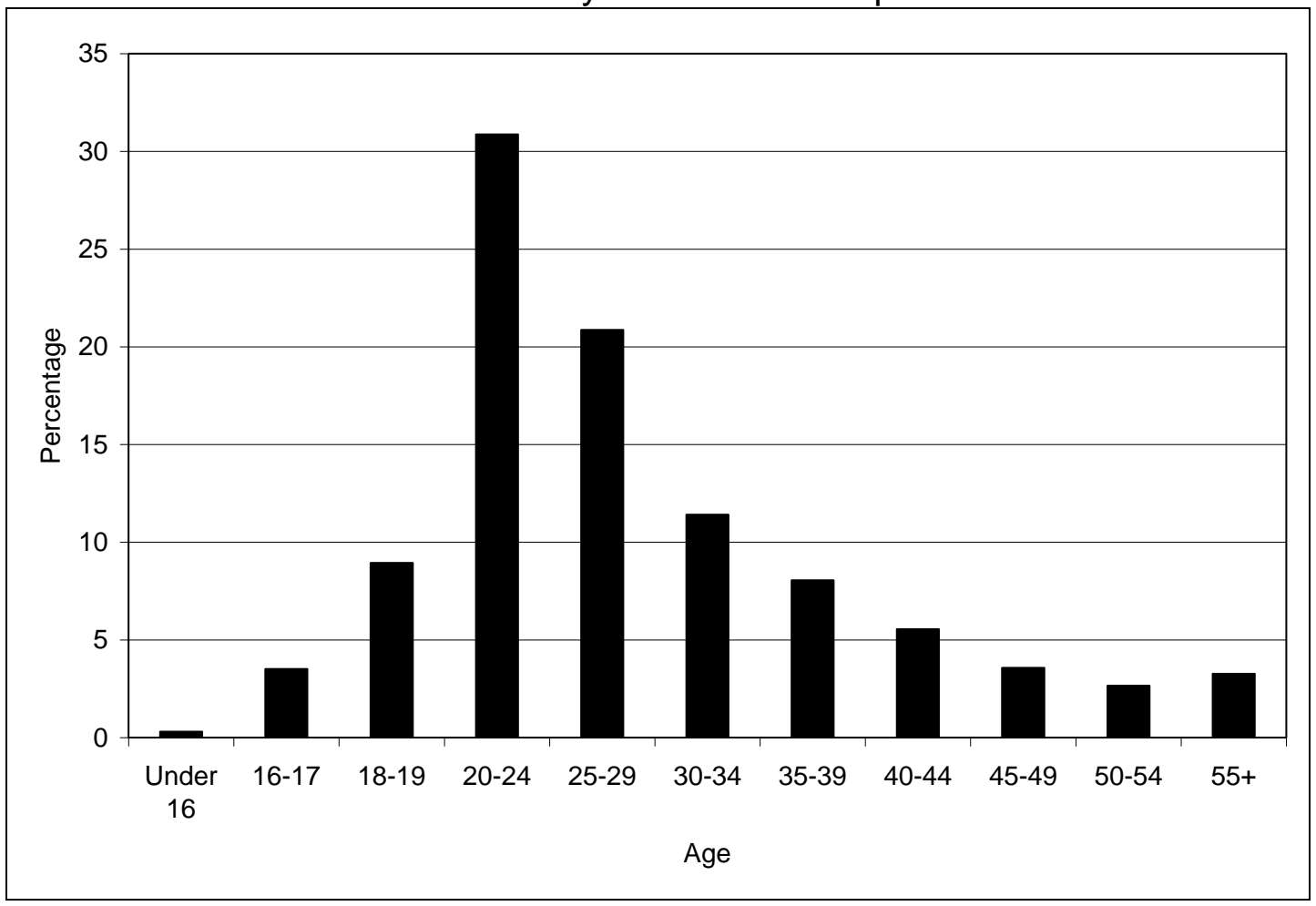

Panel B: Pennsylvania General Population by Nativity

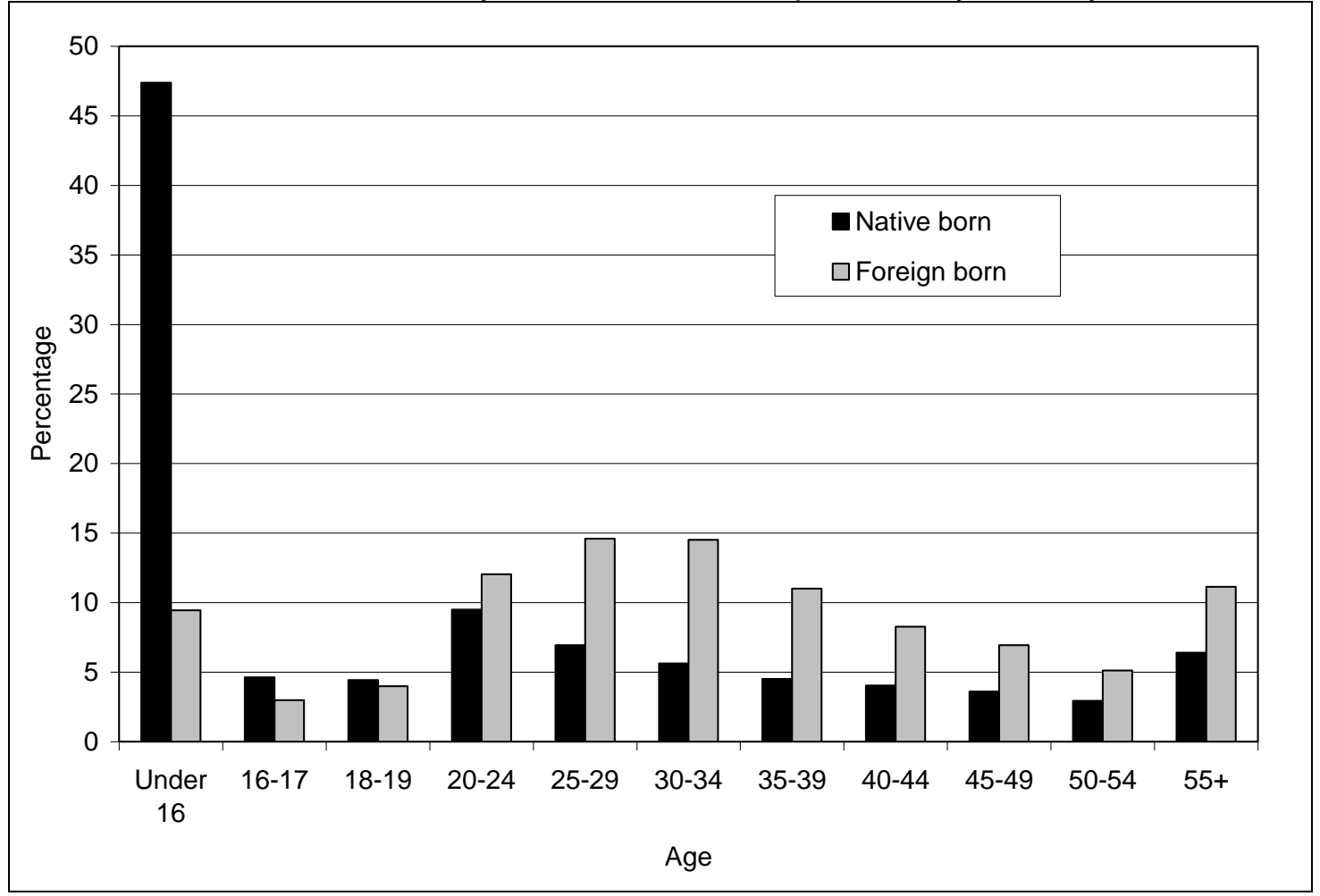


Table 1: Percentage Foreign born Prison versus General Population

\begin{tabular}{|c|c|c|c|}
\hline & \multirow[b]{2}{*}{ Prison Population } & \multicolumn{2}{|c|}{ General Population } \\
\hline & & All ages & Ages 18-44 \\
\hline All & & & \\
\hline 1840 & $\begin{array}{l}18.7 \% \\
(2624)\end{array}$ & & \\
\hline 1850 & $\begin{array}{r}26.4 \\
(2105)\end{array}$ & $13.1 \%$ & $20.4 \%$ \\
\hline 1860 & $\begin{array}{r}27.4 \\
(3278)\end{array}$ & 15.0 & 24.5 \\
\hline Females & & & \\
\hline 1840 & $\begin{array}{r}7.3 \\
(137)\end{array}$ & & \\
\hline 1850 & $\begin{array}{l}35.8 \\
(81)\end{array}$ & & 19.0 \\
\hline 1860 & $\begin{array}{r}37.1 \\
(116)\end{array}$ & & 23.6 \\
\hline Males & & & \\
\hline 1840 & $\begin{array}{r}19.3 \\
(2487)\end{array}$ & & \\
\hline 1850 & $\begin{array}{r}26.0 \\
(2024)\end{array}$ & & 21.7 \\
\hline 1860 & $\begin{array}{r}27.1 \\
(3162)\end{array}$ & & 25.4 \\
\hline White Males & & & \\
\hline 1840 & $\begin{array}{r}27.8 \\
(1681)\end{array}$ & & \\
\hline 1850 & $\begin{array}{r}32.6 \\
(1579)\end{array}$ & & 22.3 \\
\hline 1860 & $\begin{array}{r}30.8 \\
(2753)\end{array}$ & & 25.8 \\
\hline
\end{tabular}

Notes: The Pennsylvania state prison population figures were calculated from snapshots of the prison population on June 1 (the date of the federal population census) of each year in the five-year period centered on the census year. See text for more information. The numbers in parentheses represent the number of observations used in the calculations. The general population data were constructed from the IPUMS samples of the 1850 and 1860 federal census returns for Pennsylvania. The 1840 federal population census did not collect data on individual nativity. 
Table 2: Incarceration Rates by Race, Gender, and Nativity (per 100,000 persons ages 18 to 44 )

\begin{tabular}{l|cc}
\hline & 1850 & 1860 \\
\hline All males & 90 & 114 \\
All females & 4 & 4 \\
White males & 72 & 101 \\
Black males & 808 & 861 \\
Native-born males & 86 & 112 \\
White native-born males & 72 & 101 \\
White foreign-born males & 62 & 94 \\
\end{tabular}

Notes: See notes to Table 1.

Table 3: Incarceration Rates of White Males by Age and Nativity (per 100,000)

\begin{tabular}{l|cc|cc}
\hline \multirow{2}{*}{ Age category } & \multicolumn{3}{|c|}{1850} & \multicolumn{2}{c}{1860} \\
& Native born & Foreign born & Native born & Foreign born \\
\hline Under 16 & & & & 0 \\
$16-17$ & 0.13 & 0 & 27 & 29 \\
$18-19$ & 19 & 65 & 83 & 124 \\
$20-24$ & 48 & 87 & 118 & 167 \\
$25-29$ & 64 & 121 & 96 & 117 \\
$30-34$ & 56 & 94 & 59 & 80 \\
$35-39$ & 52 & 57 & 52 & 71 \\
$40-44$ & 44 & 95 & 36 & 65 \\
$45-49$ & 40 & 69 & 28 & 43 \\
$50-54$ & 24 & 58 & 28 & 60 \\
$55+$ & 18 & 38 & 12 & 38 \\
& 16 & 31 & & \\
\hline
\end{tabular}

Notes: See notes to Table 1. 
Table 4: Percentage Foreign born Prison versus General Population by Urban/Rural, White Males

\begin{tabular}{l|cc|cc}
\hline \multirow{2}{*}{ Age category } & \multicolumn{2}{|c|}{ Prison Population } & \multicolumn{2}{c}{ General Population Ages 18-44 } \\
Rural & Urban & Rural & Urban \\
\hline 1840 & $28.1 \%$ & $27.2 \%$ & & $45.1 \%$ \\
1850 & 30.5 & 35.8 & $14.8 \%$ & 48.4 \\
1860 & 27.5 & 36.6 & 17.4 & \\
\hline
\end{tabular}

Notes: See notes to Table 1. "Urban" defined as Allegheny and Philadelphia counties.

Table 5: Incarceration Rates of White Males by Age, Nativity, and Urban/Rural (per 100,000)

\begin{tabular}{c|rr|rr}
\hline \multirow{2}{*}{ Age category } & \multicolumn{3}{|c|}{ Rural } & \multicolumn{3}{c}{ Urban } \\
1850 & & & & \\
$16-17$ & & & & \\
$18-19$ & 12 & 33 & 59 & 85 \\
$20-24$ & 28 & 51 & 147 & 129 \\
$25-29$ & 48 & 107 & 153 & 140 \\
$30-34$ & 49 & 97 & 88 & 91 \\
$35-39$ & 35 & 78 & 131 & 41 \\
$40-44$ & 34 & 100 & 85 & 89 \\
$45-49$ & 37 & 139 & 55 & 20 \\
$50-54$ & 19 & 80 & 55 & 32 \\
$55+$ & 15 & 44 & 46 & 28 \\
& 11 & 29 & 76 & 36 \\
1860 & & & & \\
$16-17$ & & & & \\
$18-19$ & 15 & 42 & 72 & 21 \\
$20-24$ & 63 & 124 & 163 & 124 \\
$25-29$ & 87 & 209 & 257 & 131 \\
$30-34$ & 82 & 141 & 161 & 97 \\
$35-39$ & 56 & 93 & 70 & 67 \\
$40-44$ & 45 & 103 & 85 & 40 \\
$45-49$ & 34 & 63 & 44 & 68 \\
$50-54$ & 26 & 33 & 45 & 58 \\
$55+$ & 26 & 67 & 42 & 53 \\
& 12 & 31 & 13 & 45 \\
\hline
\end{tabular}

Notes: See notes to Table 4. 
Table 6: Crime Types by Nativity, Commitments of White Males 1830-1862

\begin{tabular}{l|cc}
\hline & Native born & Foreign born \\
\hline & & \\
Property crime & $80.2 \%$ & $72.4 \%$ \\
Crime against a person & 7.3 & 10.0 \\
Homicide & 4.7 & 9.5 \\
Arson & 3.0 & 2.9 \\
Crime against public order & 1.6 & 3.1 \\
Felony, not specified & 1.6 & 1.1 \\
Moral crime & 1.6 & 0.9 \\
Misdemeanor, not specified & 0.1 & 0.2 \\
\end{tabular}

Notes: Property crimes include larceny, burglary, counterfeiting, forgery, fraud, receipt of stolen property and the like. Crimes against a person include assault, rape, attempted murder, and robbery. Crimes against the public order include perjury, resisting arrest, gambling, and obstruction. Moral crimes in this period include prostitution, incest, pornography, and sodomy. Columns may not sum to $100 \%$ due to rounding.

Table 7: Incarceration Rates of White Males by Crime Type and Nativity (per 100,000 persons ages 18-44)

\begin{tabular}{l|cc|cc}
\hline \multirow{2}{*}{ Crime type } & \multicolumn{2}{|c|}{1850} & \multicolumn{2}{c}{1860} \\
\hline \multirow{2}{*}{ Violent } & Native born & Foreign born & Native born & Foreign born \\
Property & 10 & 22 & 17 & 39 \\
Other & 47 & 71 & 67 & 70 \\
& 5 & 11 & 10 & 12 \\
\hline
\end{tabular}

Notes: Violent crimes defined as homicide plus all crimes against persons. 
Table 8: Percentage Irish, German, and British Prison versus

General Population, White Males

\begin{tabular}{|c|c|c|}
\hline & Prison Population & General Population Ages 18-44 \\
\hline Irish & & \\
\hline 1840 & $14.2 \%$ & \\
\hline 1850 & 12.5 & $10.7 \%$ \\
\hline 1860 & 12.9 & 12.0 \\
\hline German & & \\
\hline 1840 & 6.3 & \\
\hline 1850 & 11.2 & 6.6 \\
\hline 1860 & 11.2 & 8.8 \\
\hline British & & \\
\hline 1840 & 4.2 & \\
\hline 1850 & 5.8 & 3.9 \\
\hline 1860 & 4.4 & 4.0 \\
\hline
\end{tabular}

Notes: See notes to Table 1. 
Table 9: Incarceration Rates of Irish, German, and British Male Immigrants by Age (per 100,000)

\begin{tabular}{|c|c|c|c|}
\hline Age category & Irish & Germans & British \\
\hline \multicolumn{4}{|l|}{1850} \\
\hline 16-17 & 87 & 33 & 0 \\
\hline $18-19$ & 69 & 129 & 28 \\
\hline $20-24$ & 115 & 106 & 183 \\
\hline $25-29$ & 69 & 77 & 135 \\
\hline $30-34$ & 59 & 73 & 38 \\
\hline $35-39$ & 42 & 132 & 89 \\
\hline $40-44$ & 47 & 120 & 74 \\
\hline $45-49$ & 59 & 68 & 28 \\
\hline $50-54$ & 23 & 55 & 42 \\
\hline $55+$ & 9 & 43 & 27 \\
\hline \multicolumn{4}{|l|}{1860} \\
\hline 16-17 & 0 & 0 & 180 \\
\hline $18-19$ & 153 & 69 & 67 \\
\hline $20-24$ & 154 & 170 & 117 \\
\hline $25-29$ & 104 & 116 & 150 \\
\hline $30-34$ & 56 & 97 & 72 \\
\hline $35-39$ & 69 & 85 & 49 \\
\hline $40-44$ & 58 & 64 & 62 \\
\hline $45-49$ & 27 & 77 & 18 \\
\hline $50-54$ & 65 & 78 & 32 \\
\hline $55+$ & 43 & 58 & 18 \\
\hline
\end{tabular}

Notes: See notes to Table 1.

Table 10: Crime Types, Commitments of Irish, German, and British Male Immigrants 1830-1862

\begin{tabular}{l|ccc}
\hline & Irish & Germans & British \\
\hline & & & \\
Property crime & $59.3 \%$ & $84.9 \%$ & $80.8 \%$ \\
Crime against a person & 13.0 & 6.0 & 10.15 \\
Homicide & 16.6 & 3.5 & 3.4 \\
Arson & 2.9 & 3.1 & 1.9 \\
Crime against public order & 5.7 & 0.8 & 1.1 \\
Felony, not specified & 1.3 & 1.4 & 0.4 \\
Moral crime & 1.1 & 0.4 & 1.9 \\
Misdemeanor, not specified & 0.0 & 0.0 & 0.4 \\
& & & \\
\hline
\end{tabular}

Notes: See notes to Table 6. 
Table 11: Incarceration Rates by Crime Type and Country of Birth (per 100,000 persons ages 18-44)

\begin{tabular}{c|cccc}
\hline Crime type & Native born & Irish & Germans & British \\
\hline $\begin{array}{c}1850 \\
\text { Violent }\end{array}$ & 10 & 27 & 15 & 25 \\
Property & 47 & 46 & 102 & 72 \\
Other & 5 & 11 & 6 & 9 \\
1860 & 17 & 55 & & \\
Violent & 67 & 38 & 21 & 27 \\
Property & 10 & 15 & 94 & 83 \\
Other & & & 13 & 1 \\
\hline
\end{tabular}

Notes: Violent crimes defined as homicide plus all crimes against persons. 